\title{
Failure and preventive costs of mastitis on Dutch dairy farms
}

\author{
Felix J. S. van Soest, ${ }^{* 1}$ Inge M. G. A. Santman-Berends, $†$ Theo J. G. M. Lam, $†$ and Henk Hogeveen* $\ddagger$ \\ *Business Economics Group, Social Sciences, Wageningen University, Hollandseweg 1, 6706 KN, Wageningen, the Netherlands \\ †GD Animal Health, Arnsbergstraat 7, $7418 \mathrm{EZ}$, Deventer, the Netherlands \\ ‡Department of Farm Animal Health, Faculty of Veterinary Medicine, Yalelaan 7, $3584 \mathrm{CL}$, Utrecht University, Utrecht, the Netherlands
}

\begin{abstract}
Mastitis is an important disease from an economic perspective, but most cost assessments of mastitis include only the direct costs associated with the disease (e.g., production losses, culling, and treatment), which we call failure costs (FC). However, farmers also invest time and money in controlling mastitis, and these preventive costs $(\mathrm{PC})$ also need to be taken into account. To estimate the total costs of mastitis, we estimated both FC and PC. We combined multiple test-day milk records from 108 Dutch dairy farms with information on applied mastitis prevention measures and farmers' registration of clinical mastitis for individual dairy cows. The aim was to estimate the total costs of mastitis and to give insight into variations between farms. We estimated the average total costs of mastitis to be $€ 240 /$ lactating cow per year, in which FC contributed €120/ lactating cow per year and PC contributed another $€ 120 /$ lactating cow per year. Milk production losses, discarded milk, and culling were the main contributors to FC, at €32, €20, and €20/lactating cow per year, respectively. Labor costs were the main contributor to PC, next to consumables and investments, at $€ 82$, $€ 34$, and $€ 4$ /lactating cow per year, respectively. The variation between farmers was substantial, and some farmers faced both high FC and PC. This variation may have been due to structural differences between farms, different mastitis-causing pathogens, the time at which preventive action is initiated, stockmanship, or missing measures in $\mathrm{PC}$ estimates. We estimated the minimum FC to be $€ 34$ per lactating cow per yr. All farmers initiated some preventive action to control or reduce mastitis, indicating that farmers will always have mastitis-related costs, because mastitis will never be fully eradicated from a farm. Insights into both the $\mathrm{PC}$ and FC of a specific farm will allow veterinary advisors and farmers to assess whether current udder health
\end{abstract}

Received October 26, 2015.

Accepted June 13, 2016.

${ }^{1}$ Corresponding author: felix.vansoest@wur.nl strategies are appropriate or whether there is room for improvement from an economic perspective.

Key words: dairy, mastitis, management, economics

\section{INTRODUCTION}

Mastitis, both clinical (CM) and subclinical (SCM), is endemic on dairy farms worldwide. Mastitis substantially affects animal health and welfare, as well as farm income. The different aspects of mastitis and their associated economic impact have been the focus of several previous studies. Huijps et al. (2009) estimated the costs of CM and SCM in first-parity cows at $€ 31$ per first-parity cow per yr, with a corresponding CM incidence of 0.15 per cow-year among first-parity cows. Cha et al. (2011) estimated the costs of gram-positive, gram-negative, and other mastitis-causing pathogens at $\$ 134, \$ 211$, and $\$ 95$ (US) per case, with corresponding incidence of 15.5, 12.6, and 16.2 CM cases per 100 cowyears. Similarly, Sørensen et al. (2010) found that the costs of mastitis varied from $€ 149$ to $€ 570$ per mastitis case, at an incidence of 3 to $5 \%$ per lactation, depending on the mastitis-causing pathogen. Heikkilä et al. (2012) estimated the costs of mastitis at $€ 458$ per CM case or $€ 147$ per cow per year, with a corresponding CM incidence of 0.31 to 0.38 per cow per year, depending on the type of breed. Although estimates of the costs of mastitis differ, it is clear that mastitis has a substantial effect on farm economics. As well, mastitis does not only affect farm income: costs are directed throughout the dairy processing chain and also affect processors' profitability (Geary et al., 2013).

Previous studies on the costs of mastitis only provide costs associated with production losses, culling, and treatment. Farmers, however, also invest time and money in controlling mastitis (Huijps et al., 2010), factors that are hardly ever taken into account in cost estimates. McInerney et al. (1992) have suggested making an economic distinction between expenditures and losses to estimate the total costs of a disease. Expenditures are the costs incurred by the farmer to prevent or treat a disease. Losses are the costs associated with an animal affected by clinical or subclinical disease (e.g., 
production losses, culling, discarded milk). Hogeveen et al. (2011) have suggested separating the total costs of mastitis into failure costs (FC) and preventive costs (PC). In mastitis, FC are those associated with animals who have mastitis (e.g., production losses, veterinary treatment, antibiotics) and PC are those associated with management measures to prevent mastitis.

Insights into the $\mathrm{FC}$ and $\mathrm{PC}$ associated with mastitis are only sparsely available. Fourichon et al. (2001) estimated health-control costs on dairy farms, including mastitis, but considered only health-control measures; FC were lacking. To our knowledge, only 2 studies have used a construct similar to $\mathrm{FC}$ and $\mathrm{PC}$, which they called losses and expenditures, to estimate the total costs of mastitis (McInerney et al., 1992; Yalcin et al., 1999). Yalcin et al. (1999) estimated both expenditures and losses associated with SCM in Scottish high-bulk milk SCC dairy herds and stated that $35 \%$ of the costs could be avoided. However, expenditures related to $\mathrm{CM}$, which could be substantial, were neglected in that study. McInerney et al. (1992) included farm data to estimate both CM and SCM losses but evaluated only 3 measures.

Documenting the effect of mastitis as FC shows an important factor in the economic impact of mastitis and the potential importance of its prevention. Understanding both $\mathrm{FC}$ and $\mathrm{PC}$ will give a more complete insight into the total costs associated with mastitis. In our study, we used information on farm-specific udder-health management strategies, farmer-registered $\mathrm{CM}$ incidence, and multiple test-day milk records to determine the total costs of mastitis. Our aim was to estimate the total costs of mastitis as a construct of FC and $\mathrm{PC}$ and to provide insight into variations between farms.

\section{MATERIALS AND METHODS}

\section{Dairy Herds}

Data from 108 Dutch dairy herds were available from previous work conducted by Santman-Berends et al. (2012). Herds were representative of Dutch dairy herds with more than 50 lactating cows, of which the herd owner was younger than 50 yr. Farmers reported the number of cases of CM from January 2005 to December 2009. During this period, participating farmers were requested every month, by e-mail, to report the number of $\mathrm{CM}$ cases in the previous month. If they did not reply, follow-up calls were made.

Test-day milk record data were collected from all dairy cows in participating herds that were present from January 2007 to December 2009. Test-day milk record data were provided by the Dutch Royal Cattle
Syndicate (CRV, Arnhem, the Netherlands) and contained information on individual cow records (milk production, SCC, date of calving, date of culling, and date of test-day record) for each of the participating herds. We used test-day milk record data to determine the number of days each dairy cow was in lactation and the associated milk production losses during the study period.

In spring 2008, farmers were asked to complete a questionnaire that included questions on mastitis management, milking process and technique, and mastitis and dry cow treatment. We derived a list of preventive management measures from the questionnaire. Information on the applied measures was valid for 2008 and was used to estimate PC for that year. The collected technical data, farmers' reports on CM cases, test-day milk record data, and questionnaire data were set to be representative for January 1, 2008, to December 31, 2008. More information on the data used can be found in Santman-Berends et al. (2012).

\section{Total Costs of Mastitis}

The total costs of mastitis were the sum of FC and PC.

Failure Costs. Mastitis FC were divided into direct and indirect costs. Direct costs included those associated with treatment, such as veterinary visits and medication. Indirect costs were those associated with the consequences of SCM and CM, such as milk production losses and culling.

Milk production losses for SCM were estimated at the cow level and based on the SCC of individual cows for each test-day record. Based on Halasa et al. (2009), we assumed that an individual cow did not meet its potential milk production when SCC was elevated (SCC $>50,000$ cells $/ \mathrm{mL}$ ). For dairy cow $i$, potential milk production $\left(Y_{P O T i j}\right)$, expressed in kilograms of milk per day, was determined as a function of $S C C_{i j}$ and realized daily milk production $\left(Y_{i j}\right)$ at test-day record date $j$. Potential milk production was estimated for primiparous cows (age at the start of lactation $<1,030 \mathrm{~d}$ ) as

$$
Y_{\text {POTij }}=Y_{i j}+\left[0.72+\ln \left(S C C_{i j}-0.22\right)\right],
$$

and for multiparous cows (age at the start of lactation $\geq 1,030 \mathrm{~d})$ as

$$
Y_{\text {РОTij }}=Y_{i j}+\left[1.9+\ln \left(S C C_{i j}-0.47\right)\right] .
$$

For both primiparous and multiparous dairy cows with a SCC $\leq 50,000$ cells $/ \mathrm{mL}, Y_{\text {POTij }}$ was assumed equal to $Y_{i j}$. 
To estimate milk production losses at farm level, test-day records were converted to test-day periods and finally merged to the farm level. Test-day periods could be the period from (1) the test-day record date to the next test-day record date; (2) the test-day record date to the date of removal from the herd; (3) the testday record date to the dry-off date; or (4) the date of calving to the test-day record date. For each testday period, we determined information on daily milk production (both potential and realized) at the start and end of the period, as well as the number of days in that period. Because daily milk production was not known at removal or dry-off dates, for test-day periods that included either a removal or drying off, daily milk production at the start equaled milk production at the end, and vice versa. If no date of removal was registered, dairy cows were assumed removed from the herd (either by death, sale, or culling) at the last recorded test-day date. Date of drying off was not registered and was therefore determined as the date of the following calving minus the average dry period of Dutch dairy cows in 2008 (64 d; CRV, 2010). When this resulted in a negative number, the last known test-day record date within the corresponding parity was set as the date of drying off. For test-day periods with a start or end outside the study period, only milk production from January 1 to December 31 was considered. Assuming that daily milk production between the start and end date of a test-day period changed linearly, we determined milk production on either January 1, 2008, or December 31, 2008, using linear interpolation. For each test-day period, we determined milk production (realized and potential) as the area under the curve, assuming that daily milk production at the start and end of each period was linear. Finally, total milk production per farm in 2008 (realized and potential) was estimated as the total amount of produced milk on the farm. The difference between total realized and potential milk production per farm in 2008 was assumed the milk production loss due to SCM.

In the available data, CM cases were not linked to individual dairy cows. Therefore, each case of CM was assumed to have a relative total milk production loss of $5 \%$ of the average realized milk production of a dairy cow on a specific farm (Seegers et al., 2003). Because we calculated milk production losses independently for $\mathrm{CM}$ as well as for increased SCC, losses might be overestimated. In the sensitivity analysis (described below), we have explored the effects of this possible overestimation.

The FC of CM included milk production losses, discarded milk, culling, and treatment (including veterinary visits, medication, and labor). Cost calculations were based on Huijps et al. (2008). As of 2015, the
EU milk quota system was abolished. Contrary to the quota situation and using the marginal costs of milk, producing $1 \mathrm{~kg}$ of milk extra now equals the milk price. This means that the economic loss of losing $1 \mathrm{~kg}$ of milk equaled the milk price minus the price of concentrates. Discarding $1 \mathrm{~kg}$ of milk equaled the milk price plus the price of concentrates. Although the technical data were representative for farms in 2008, the costs estimates in this study were based on 2015 price levels to correspond to the current farming situation in the Netherlands. It was assumed that the milk produced by a cow treated with antibiotics was discarded during the withdrawal period. The milk price was assumed to be $€ 0.41 / \mathrm{kg}$ of milk, and the feed price of concentrates was assumed to be $€ 0.07 / \mathrm{kg}$ of milk (LEI, 2015). We used the average daily production per cow on a farm to estimate the amount of milk discarded due to treatment. We assumed that the duration of treatment and corresponding withdrawal period was $6 \mathrm{~d}$, and that $80 \%$ of all animals diagnosed with CM were treated with antibiotics. Labor costs were based on the amount of labor spent on treating each case of CM, multiplied by the hourly wage of the farmer. The hourly wage was assumed to be the price of hired labor and was set at $€ 20 / \mathrm{h}$ (Vermeij, 2014). Veterinary visits were assumed to occur in $5 \%$ of all $\mathrm{CM}$ cases, and $15 \%$ of all cows with $\mathrm{CM}$ were assumed culled due to mastitis. An overview of both technical and economic assumptions for estimating FC are presented in Table 1.

Preventive Costs. Mastitis PC involved those associated with farm management measures implemented to prevent mastitis. The PC of each measure generally consisted of 3 cost factors: labor, consumables, and investments. Labor was the time necessary to perform the measure. Consumables were expenditures on used goods. Investments were the depreciation costs of materials lasting longer than a year, plus associated interest. We assumed that both labor and consumables were used half of the time when a farmer indicated that the respective management measure was applied "sometimes." Investments were not affected by the number of times a measure was applied.

The measures, derived from the questionnaire, were related to prevention of mastitis and could be implemented on the farm in the short term. Measures were clustered in 4 categories: a clean, dry, comfortable environment; proper milking procedure; proper maintenance and use of milking equipment; and dry cow management. Management measures related to a clean, dry, comfortable environment involved keeping cow traffic areas clean and dry; keeping cow lying areas clean and dry; and ensuring cows remained standing after milking by feeding and locking them with feeding bars. Management measures related to proper milking 
procedures involved pre-stripping; wearing clean gloves during milking; washing dirty udders before milking; applying postmilking teat disinfectant; and milking cows with confirmed high SCC last. Management measures related to proper management and use of milking equipment involved thoroughly washing and sanitizing clusters after milking a case of CM. The dry cow management measure was the use of antibiotics to dry off cows. Table 2 provides an overview of the assumptions associated with each of the included management measures and the frequency with which each measure was applied.

Cost estimates of all measures were based on herd characteristics (e.g., number of dairy cows, CM incidence rate) combined with assumptions about price levels and technical input. Price levels were based on information from different suppliers and were representative for 2015. Technical input was related to the amount of materials used (e.g., water for cleaning or disinfectant). When no information was available, we consulted appropriate experts. For "clean lanes," we divided labor costs into labor necessary to start the measure and labor needed per cubicle. "Clean cubicles" included labor costs and use of extra bedding material. "Fixate cows after milking," included costs to install the feeding gate and labor to lock the cows directly after milking. "Pre-stripping" included only labor costs. "Milkers' gloves" included the costs of the gloves. "Washing dirty udders," included the costs and labor time of drying udders; we assumed that $5 \%$ of cows had a dirty udder. "Teat disinfectant" included the costs of disinfectant and the labor for application. "Milking high-SCC cows last" included labor to register cows with a high SCC (SCC >250,000 cells $/ \mathrm{mL}$ ) after each test-day date, labor to separate high SCC cows before each milking, and investment in a separation fence. "Rinsing a cluster after milking a clinical case" was as- sumed to include labor and water for cleaning. "Drying off" included labor for the application of antibiotics and the costs of the antibiotics.

\section{Sensitivity Analysis}

In our basic model, we estimated milk production losses caused by CM and SCM independently of each other. This was likely to result in an overestimation of total milk production losses, and thus the FC, of mastitis. Therefore, in a sensitivity analysis, we estimated the FC assuming that milk production losses were attributable only to SCM, likely underestimating total milk production losses. We also estimated total milk production losses in a scenario in which SCM milk production losses were proportionally corrected and CM milk production losses were similar to those in the basic model. In this situation, we assumed an overlap between SCM and CM milk production losses, because some cows with SCM will develop subsequent CM (van den Borne et al., 2010). For each farm, we reduced the total SCM milk production losses using a farm-specific proportion. This farm-specific proportion was the cases of CM divided by the cases of SCM on that farm. For instance, if 30 cases of CM were reported out of 100 SCM cases, the milk production losses due to SCM would be reduced with a farm-specific proportion of 0.3 .

We expected that economic assumptions about milk price and labor costs would have a substantial effect on the total costs of mastitis. Whereas milk price affects only FC, labor costs affect both FC and PC. The total costs of mastitis were estimated with low and high milk prices of $€ 31 / 100 \mathrm{~kg}$ of milk and $€ 51 / 100 \mathrm{~kg}$ of milk, respectively, and low and high labor costs of $€ 10 / \mathrm{h}$ and $€ 30 / \mathrm{h}$, respectively.

Table 1. Overview of market and price assumptions and other assumptions to estimate failure and preventive costs

\begin{tabular}{lr}
\hline Assumption & Value \\
\hline Market and price assumptions & 0.41 \\
Milk price $(€ / \mathrm{kg}$ of milk) & 0.07 \\
Price of concentrates $(€ / \mathrm{kg}$ of milk) & 22 \\
Cost of antibiotics for treatment $(€ /$ treatment) & 22 \\
Cost of veterinary visits $€ /$ visit) & 20 \\
Cost of labor $(€ / \mathrm{h})$ & 480 \\
Cost of culled cow $(€ /$ cow) & 5 \\
Other assumptions & 3 \\
Milk production loss per case of clinical mastitis $(\%$ of 2008 realized farm production) & 6 \\
Duration of treatment for clinical mastitis (d) & 45 \\
Duration of total withdrawal time of clinical mastitis $(\mathrm{d})$ & 5 \\
Labor for treatment of clinical mastitis (min/case) & 15 \\
Veterinary visits (\% of cases) & 2 \\
Culling (\% of clinical cases) & \\
Milkings per day & \\
\hline
\end{tabular}




\section{RESULTS AND DISCUSSION}

\section{Descriptive Statistics}

Descriptive statistics of the 108 herds included in this study are presented in Table 3. The average herd size was 86 dairy cows, greater than the Dutch average for the same period of 75 dairy cows (CRV, 2010). Inclusion criteria affected average herd size directly, and herds could generally be described as larger herds with a focus on udder health management. The average production of $27 \mathrm{~kg}$ of milk/d was slightly higher than the Dutch average of $26.3 \mathrm{~kg}$ of milk/d in 2008 . The incidence of $\mathrm{CM}$ was $27 \%$, and the average SCC was 192,000 cells $/ \mathrm{mL}$. Although farmers' reports on the number of CM cases could have been over- or underes- timated, we believe that, given the clear definition of $\mathrm{CM}$, farmers' experience, and our regular contact with the farmers, reports on CM were as close as possible to the actual number of $\mathrm{CM}$ cases.

On average, 9 test-day records were present for each cow. The method we used to estimate milk production lacked the typical smooth lactation curve, with peak milk production in early lactation and leveling out in late lactation. Fitting individual lactation curves using the basic curve of Wood (1967) or more complex curves such as Rook et al. (1993) or Dijkstra et al. (1997) resulted in inconsistent parameters, because most dairy cows did not follow the assumed smooth lactation curve. Hence, we were not able to estimate reliable production curves at the individual cow level. However, in our study we were interested in milk production losses,

Table 2. Overview of the individual management measures, their application, and corresponding assumed cost factors used as inputs to estimate preventive costs

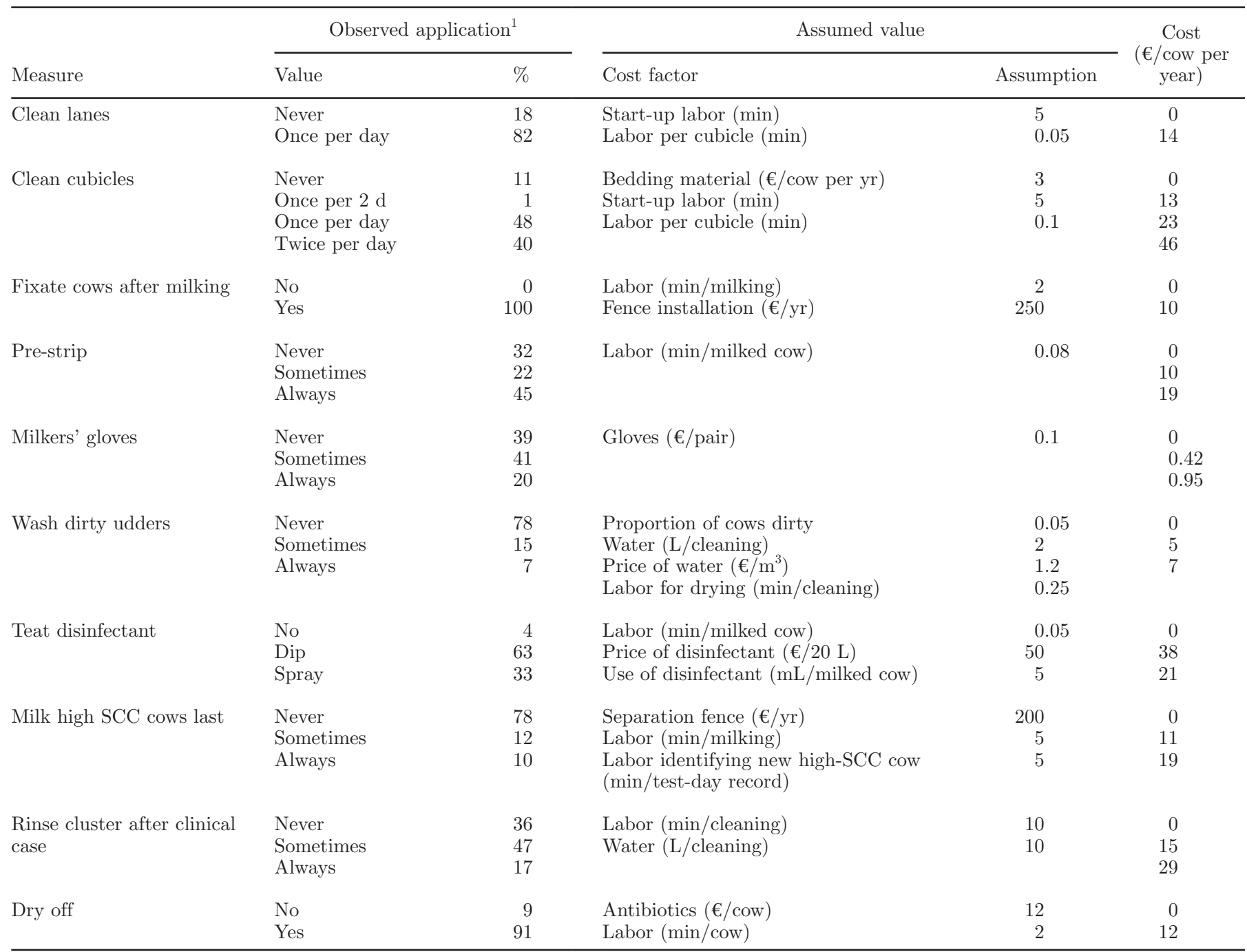

\footnotetext{
${ }^{1}$ By each of the 108 farmers.
} 
the difference between realized and potential milk production on a farm, and decided that the interpolation method we used was sufficient.

We estimated average SCM milk production losses of $107 \mathrm{~kg}$ of milk per lactating cow per year. Other studies found SCM milk production losses between 85 and 155 $\mathrm{kg}$ for first-parity cows (Dürr et al., 2008; Halasa et al., 2009) and estimated average milk production losses of $445 \mathrm{~kg}$ of milk in multiparous cows (Hagnestam-Nielsen et al., 2009). The milk production losses in our study were assumed to occur when the SCC was $>50,000$ cells/mL (Halasa et al., 2009). This is in line with the suggested threshold at which SCM milk production losses occur (Hortet and Seegers, 1998a). Despite this, estimated milk production losses due to SCM were relatively low compared with that in other studies. This may have been a reflection of the health status of the study population. Alternatively, it may have been a consequence of the long-term involvement of farmers reporting mastitis problems from 2005 onwards, and thus a better awareness of mastitis problems.

We estimated CM milk production losses at an average of $336 \mathrm{~kg}$ milk per case of CM. In a review of Hortet and Seegers (1998b), milk production losses associated with CM were estimated at 300 to $400 \mathrm{~kg}$ milk per case of CM. Nevertheless, in the same study, the authors found a large variation between cases of CM, from 150 to $1,050 \mathrm{~kg}$ of milk loss per lactation. Similarly, Hagnestam et al. (2007) showed that, within a lactation, the stage of lactation of a CM case strongly affected the magnitude of milk production losses. In our study, per farm, each case of CM had the same milk production losses. The natural variation in milk production losses between individual dairy cows on a farm was thereby neglected. However, in our study we were interested in the milk production loss at the farm level and not at the cow level, so we considered our estimates to be appropriate.

\section{Failure Costs}

The average FC were $€ 120$ per lactating cow per year (Table 4), with a minimum and maximum of $€ 34$ and
$€ 290$ per lactating cow per year, respectively. The average FC per case of CM was €301. In terms of total FC, $\mathrm{CM}$ contributed more than SCM, at $€ 83$ and $€ 37$ per lactating cow per year, respectively. Milk production losses, discarded milk, and culling contributed most to the FC of $\mathrm{CM}$, at $€ 32, € 20$, and $€ 20$ per lactating cow per year, respectively. The average FC of SCM were $€ 37$ per lactating cow per year and varied between $€ 15$ and $€ 65$ per lactating cow per year. Milk production losses are invisible and may not be experienced as a cost factor by farmers. Although farmers may be aware of milk production losses due to mastitis, they may not be aware of their economic impact (Huijps et al., 2008). Therefore, insights in these costs are valuable to farmers.

Costs of culling was a major contributor to the FC of CM. A disadvantage of our study was that we were not able to link CM cases to individual cows in the test-day record data. Therefore, we did not know to what extent culling could be associated with CM. Having this information would have led to a more accurate estimate of the expected economic value of an individual cow. Nevertheless, because reasons for culling are most often multifactorial (Bascom and Young, 1998), determining which cows were culled due to persistent mastitis problems would remain a difficult task.

\section{Preventive Costs}

Average total PC were $€ 120$ per lactating cow per year, of which labor costs were the main contributor (68\%). The PC varied between $€ 48$ and $€ 180$ per lactating cow per year. Out of the 10 preventive measures derived from the questionnaire, 5 were from the top 10 most effective measures for a $100 \%$ environmental or $100 \%$ contagious mastitis problem, as found in the study of Hogeveen et al. (2011). Huijps et al. (2010) suggested 18 measures to control mastitis, of which 10 were included in our study. The PC used in our study may underestimate true PC, because not all possible measures were included.

From the questionnaires, we established that all farmers fixated cows after milking, and that farmers applied

Table 3. Description of the average herd characteristics of 108 Dutch dairy farms ${ }^{1}$

\begin{tabular}{|c|c|c|c|c|}
\hline Item & Mean & Median & Minimum & Maximum \\
\hline Milk production loss, subclinical mastitis (kg/lactating cow per year) & 107 & 81 & 7 & 262 \\
\hline Milk production loss, clinical mastitis (kg/case per year) & 336 & 338 & 202 & 422 \\
\hline $\mathrm{SCC}\left(\times 10^{3}\right.$ cells $\left./ \mathrm{mL}\right)$ & 192 & 81 & 73 & 378 \\
\hline Daily milk production (kg of milk/d) & 27 & 27 & 16 & 35 \\
\hline
\end{tabular}

${ }^{1}$ Subclinical mastitis milk production losses were determined as the difference between realized milk production and potential milk production; clinical mastitis milk production losses were determined as a fixed percentage of the average milk production per cow on a farm for each case. 
Table 4. Failure costs and prevention costs expressed in $€$ /lactating cow per year and split into 5 different scenarios: base scenario, low milk price, high milk price, low labor costs, and high labor costs

\begin{tabular}{|c|c|c|c|c|c|}
\hline Variable & $\begin{array}{c}\text { Base } \\
\text { scenario }\end{array}$ & $\begin{array}{l}\text { Low milk price } \\
\quad(€ 0.31 / \mathrm{kg})\end{array}$ & $\begin{array}{l}\text { High milk price } \\
\quad(€ 0.51 / \mathrm{kg})\end{array}$ & $\begin{array}{l}\text { Low labor costs } \\
\quad(€ 10 / \mathrm{h})\end{array}$ & $\begin{array}{l}\text { High labor costs } \\
\qquad(€ 30 / \mathrm{h})\end{array}$ \\
\hline Milk losses, clinical mastitis & 32 & 23 & 42 & 32 & 32 \\
\hline Labor & 4 & 4 & 4 & 2 & 6 \\
\hline Antibiotics & 6 & 6 & 6 & 6 & 6 \\
\hline Culling & 20 & 20 & 20 & 20 & 20 \\
\hline Total failure costs & 120 & 96 & 144 & 118 & 122 \\
\hline Labor & 82 & 82 & 82 & 49 & 116 \\
\hline Consumables & 34 & 34 & 34 & 34 & 34 \\
\hline Investments & 4 & 4 & 4 & 4 & 4 \\
\hline Total prevention costs & 120 & 120 & 120 & 87 & 154 \\
\hline Total mastitis costs & 240 & 216 & 264 & 204 & 276 \\
\hline
\end{tabular}

${ }^{1}$ For each scenario, all other costs remained equal to the base scenario.

an average of 7 preventive measures. Only 2 farmers applied all 10 preventive measures. The average costs of each measure and the frequency of application are described in Table 2. Washing dirty udders and milking high SCC cows last were applied least often. The management measures applied most often were teat disinfection (96\%) and drying off (91\%). In our study, we found a large variation in the applied preventive strategies between farms. The decision to implement a specific combination of measures will most likely be based on multiple factors, such as perceived efficacy, cost, herd situation, veterinary advice, and personal preference. Considering all these factors makes it difficult for farmers to decide which combination of measures represents the optimal strategy. As most farmers tend not to value their own labor (Huijps et al., 2008), they may need more economic guidance to come to a good decision about which measures to apply on their farm.

\section{Total Costs of Mastitis}

The average total costs of mastitis were $€ 240$ per lactating cow per year. A scatterplot of the total costs for each farm is provided in Figure 1, in which each point represents the corresponding $\mathrm{PC}$ and $\mathrm{FC}$ for a farm expressed in $€$ /lactating cow. The total costs of mastitis varied between $€ 120$ and $€ 438$ per lactating cow per year, with a corresponding FC and PC of $€ 72$ and $€ 48$ and $€ 262$ and $€ 176$ per lactating cow per yr, respectively. Because some level of clinical and subclinical mastitis always occurred in the study herds, we calculated FC to be $€ 34$ per lactating cow per year at a minimum. Because of this, farmers will always apply preventive measures on their farm, and PC will always occur, PC was calculated to be $€ 48$ per lactating cow per year at a minimum.

We found a large variation in FC and $\mathrm{PC}$ between farms, and in some cases farmers could have both high FC and PC. We expected that a relatively high PC would lead to lower FC, and vice versa (Hogeveen et al., 2011), but we did not observe this in our study. The large variation between farms may have had different reasons, such as differences in housing systems, pasture access, or milking systems. Structural differences between farms may limit farmers in further reducing FC when PC are increased. Second, farmers with a high incidence of $\mathrm{CM}$ or large amount of cows with high SCC in their herd may be more likely to initiate preventive measures. As well, the time the preventive measure was implemented could have influenced the magnitude of the effect of PC on FC. Farmers who initiated preventive measures earlier could have already benefited from PC investments via a reduction in FC. Third, there is a large variation in mastitis-causing pathogens, which may lead to a large variation in the severity and required therapy of $\mathrm{CM}$ cases in a herd (Wilson et al., 1999; Deluyker et al., 2005). A fourth explanation could be related to stockmanship and attitude, which results in different applications of the same preventive measures between farmers (Coleman et al., 1998; Seabrook and Wilkinson, 2000). Finally, although we included most measures in our model (Dufour et al., 2011), we may have been missing some, such as adding appropriate minerals to the feed of dry cows and replacing teat cup liners according to the manufacturer's norm. However, we could not include these measures in our study because the information on the included measures were taken from a study performed earlier (Santman-Berends et al., 2012). Although we 


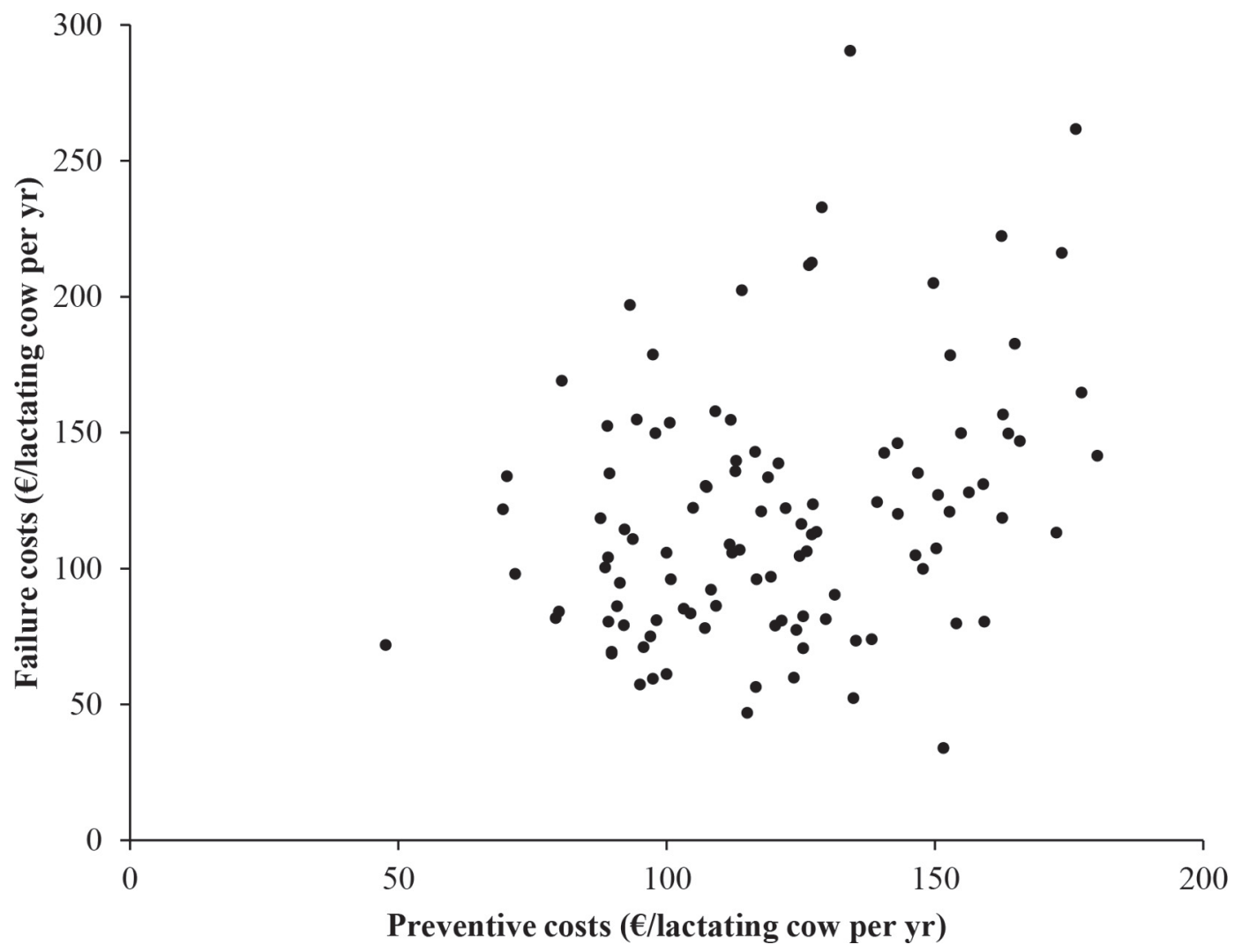

Figure 1. Estimated average failure and preventive costs associated with mastitis $(€ /$ lactating cow per yr) per herd. Each point represents an individual dairy farm $(\mathrm{n}=108)$.

could have asked farmers for extra information, it is doubtful whether farmers would remember the preventive measures they applied in 2008.

A potential benefit of preventive mastitis measures is that some may also improve overall animal health status. Management measures that improve general hygiene, such as cleaning cubicles and cleaning lanes, could have had a positive effect on claw health status (Hultgren and Bergsten, 2001) and lowered the FC of lameness. Given the interaction between mastitis, lameness, ketosis, and reproductive disorders (Berge and Vertenten, 2014), a decrease in 1 of these diseases could result in a reduced risk of developing any of the others. This suggests that the current model may underestimate the potential gains of a measure, because FC included only the costs associated with mastitis. Ideally, exploring the total costs of any production disease as a construct of both FC and PC should be placed in a broader perspective in which the most common production diseases and intervention strategies are included. Currently, good animal health information is scarce on all of these diseases at the farm level, together, and the interaction between them. It is currently impossible to give a good farm-specific estimate of the $\mathrm{PC}$ and $\mathrm{FC}$ of all these diseases.

Economic considerations are an important reason for farmers to implement changes on their farm. Given the substantial economic impact of mastitis, gaining insights in the FC and PC of mastitis is useful information for farmers and veterinary advisors. Today, most veterinary advisors have access to relatively good data on which mastitis prevention measures are applied on farms and the health status of a herd with regard to mastitis. Therefore, they may be able to calculate the FC and PC for their clients and advise on how to improve udder health management. Comparisons between farms could lead to discussions about economic costs and losses associated with mastitis, together with the farmers' current management practice. An important reason for farmers' nonadherence with a veterinary herd health advice is expected high costs and low returns (Derks et al., 2012). Veterinary advice costs were not included in the PC in this study. Including the costs of veterinary advice in the PC puts veterinary 
advice in perspective relative to other applied management measures and may lead to higher adherence to veterinary advice.

\section{Sensitivity Analysis}

The use of test-day records and farm recordings to estimate the total costs of mastitis has some limitations. Including milk production losses due to both SCM and CM may have led to overestimates in our calculations. Moreover, the value of the major cost factors (labor costs and milk price) were not available from farms directly, rely on market price assumptions, and can differ per farm.

In the basic model, milk production losses included due to both SCM and CM. A scenario that assumed no milk production loss for a case of CM was expected to be on the low end of the milk production loss estimates. In this scenario, the average FC were estimated to be $€ 87$ per lactating cow per year, with a minimum and maximum of $€ 29$ and $€ 199$ per lactating cow per year, respectively. In the third scenario, SCM milk production losses were corrected with a farm-specific proportion, and $\mathrm{CM}$ milk production losses were kept the same. This resulted in an average FC of $€ 114$ per lactating cow per year and a minimum and maximum of $€ 33$ and $€ 272$ per lactating cow per year, respectively. To our knowledge, no studies have reported the relation between SCC and CM regarding milk production losses or any carry-over effect between them, so we are not certain whether assuming additional milk production loss of a case of CM is better than assuming no milk production loss at all or using a proportional correction. We believe that most reported cases of CM would likely not have been present on one of the test dates. Milk delivered by case of CM is typically withdrawn and not recorded in the test-day records. Nevertheless, if milk production losses were assumed to be lower, losses due to mastitis would still be substantial and, more important, the variation between farms remained large.

The cost estimates found in our study were higher than previous cost estimates on mastitis in the Netherlands that were made under the quota system (Huijps et al., 2009; Hogeveen et al., 2011). The total costs of mastitis were estimated for an average expected milk price, a low milk price (€31/100 kg of milk) and a high milk price (€51/100 kg of milk). The average FC at a low milk price were $€ 69$ per lactating cow per year and varied between $€ 6$ and $€ 204$ per lactating cow per year. The average FC at a high milk price were $€ 144$ per lactating cow per year and varied between $€ 42$ and $€ 343$ per lactating cow per year. Milk price affects the costs of mastitis substantially; with an increasing milk price, the need the improve udder health status and reduce $\mathrm{FC}$ becomes more important.

Labor costs affect both FC and PC. The value of labor was not available for individual farms, but we evaluated the labor costs for a base situation, a scenario with low labor costs $(€ 10 / \mathrm{h})$ and a scenario with high labor costs $(€ 30 / \mathrm{h})$ to gain insights in the effect of labor costs on the total costs of mastitis. Both preventive measures and treatment of cows suffering from mastitis involve labor, so both PC and FC were affected when labor costs changed. At a herd level, high labor costs were associated with average total mastitis costs of $€ 276$ per lactating cow per year and varied between $€ 131$ and $€ 510$ per lactating cow per year. Low labor costs were associated with average total mastitis costs of €204 per lactating cow per year and varied between $€ 108$ and $€ 371$ per lactating cow per year. Given that labor was the most important factor in $\mathrm{PC}$, it is important for farmers to value their own labor. As mentioned earlier, incorrect estimates of farmers' labor may affect decision-making on a farm.

Assumptions for labor costs and milk price influenced the total costs of mastitis substantially. Although the absolute levels of FC and PC may vary depending on the assumptions made, our conclusion remains valid that economic costs associated with mastitis vary greatly between farmers, leaving room for improvement. It is important for farmers to gain insights in their personal economic situation related to mastitis, and better understand where the costs of mastitis can be further reduced.

\section{CONCLUSIONS}

Total costs of mastitis based on the combination of $\mathrm{PC}$ and FC were estimated at $€ 240$ per lactating cow per year. A minimum amount of loss due to FC and minimum amount of $\mathrm{PC}$ associated with mastitis would always occur. Furthermore, we found large variation between farms in the total costs of mastitis, and this may indicate that farmers can improve their economic situation with regard to mastitis control.

\section{ACKNOWLEDGMENTS}

We acknowledge the farmers that participated in this study and CRV (Arnhem, the Netherlands) for providing the test-day milk record data.

\section{REFERENCES}

Bascom, S. S., and A. J. Young. 1998. A summary of the reasons why farmers cull cows. J. Dairy Sci. 81:2299-2305. http://dx.doi. org/10.3168/jds.S0022-0302(98)75810-2. 
Berge, A. C., and G. Vertenten. 2014. A field study to determine the prevalence, dairy herd management systems, and fresh cow clinical conditions associated with ketosis in western European dairy herds. J. Dairy Sci. 97:2145-2154. http://dx.doi.org/10.3168/ jds.2013-7163.

Cha, E., D. Bar, J. A. Hertl, L. W. Tauer, G. Bennett, R. N. González, Y. H. Schukken, F. L. Welcome, and Y. T. Gröhn. 2011. The cost and management of different types of clinical mastitis in dairy cows estimated by dynamic programming. J. Dairy Sci. 94:44764487. http://dx.doi.org/10.3168/jds.2010-4123.

Coleman, G., P. Hemsworth, and M. Hay. 1998. Predicting stockperson behaviour towards pigs from attitudinal and job-related variables and empathy. Appl. Anim. Behav. Sci. 58:63-75. http:/ dx.doi.org/10.1016/S0168-1591(96)01168-9.

CRV (Dutch Royal Cattle Syndicate). 2010. Year statistics. CRV Arnhem, the Netherlands. Accessed Jul. 14, 2016. https://www. crv4all.nl/downloads/prestaties/jaarstatistieken/.

Deluyker, H. A., S. N. Van Oye, and J. F. Boucher. 2005. Factors affecting cure and somatic cell count after pirlimycin treatment of subclinical mastitis in lactating cows. J. Dairy Sci. 88:604-614. http://dx.doi.org/10.3168/jds.S0022-0302(05)72724-7.

Derks, M., L. M. A. van de Ven, T. van Werven, W. D. J. Kremer, and H. Hogeveen. 2012. The perception of veterinary herd health management by Dutch dairy farmers and its current status in the Netherlands: A survey. Prev. Vet. Med. 104:207-215. http:// dx.doi.org/10.1016/j.prevetmed.2011.12.019.

Dijkstra, J., J. France, M. S. Dhanoa, J. A. Maas, M. D. Hanigan, A. J. Rook, and D. E. Beever. 1997. A model to describe growth patterns of the mammary gland during pregnancy and lactation. J. Dairy Sci. 80:2340-2354. http://dx.doi.org/10.3168/jds.S00220302(97)76185-X.

Dufour, S., A. Fréchette, H. W. Barkema, A. Mussell, and D. T. Scholl 2011. Invited review: Effect of udder health management practices on herd somatic cell count. J. Dairy Sci. 94:563-579. http://dx.doi. org/10.3168/jds.2010-3715.

Dürr, J. W., R. I. Cue, H. G. Monardes, J. Moro-Méndez, and K. M. Wade. 2008. Milk losses associated with somatic cell counts per breed, parity and stage of lactation in Canadian dairy cattle. Livest. Sci. 117:225-232. http://dx.doi.org/10.1016/j.livsci.2007.12.004.

Fourichon, C., H. Seegers, F. Beaudeau, L. Verfaille, and N. Bareille. 2001. Health-control costs in dairy farming systems in western France. Livest. Prod. Sci. 68:141-156. http://dx.doi.org/10.1016/ S0301-6226(00)00248-7.

Geary, U., N. Lopez-Villalobos, B. O'Brien, D. J. Garrick, and L. Shalloo. 2013. Examining the impact of mastitis on the profitability of the Irish dairy industry. Ir. J. Agric. Food Res. 52:135-149.

Hagnestam, C., U. Emanuelson, and B. Berglund. 2007. Yield losses associated with clinical mastitis occurring in different weeks of lactation. J. Dairy Sci. 90:2260-2270. http://dx.doi.org/10.3168/ jds.2006-583.

Hagnestam-Nielsen, C., U. Emanuelson, B. Berglund, and E. Strandberg. 2009. Relationship between somatic cell count and milk yield in different stages of lactation. J. Dairy Sci. 92:3124-3133. http:// dx.doi.org/10.3168/jds.2008-1719.

Halasa, T., M. Nielen, A. P. W. De Roos, R. Van Hoorne, G. de Jong, T. J. G. M. Lam, T. van Werven, and H. Hogeveen. 2009. Production loss due to new subclinical mastitis in Dutch dairy cows estimated with a test-day model. J. Dairy Sci. 92:599-606. http:// dx.doi.org/10.3168/jds.2008-1564.

Heikkilä, A. M., J. I. Nousiainen, and S. Pyörälä. 2012. Costs of clinical mastitis with special reference to premature culling. J. Dairy Sci. 95:139-150. http://dx.doi.org/10.3168/jds.2011-4321.

Hogeveen, H., K. Huijps, and T. J. G. M. Lam. 2011. Economic aspects of mastitis: new developments. N. Z. Vet. J. 59:16-23. http://dx.doi.org/10.1080/00480169.2011.547165.
Hortet, P., and H. Seegers. 1998a. Calculated milk production losses associated with elevated somatic cell counts in dairy cows: Review and critical discussion. Vet. Res. 29:497-510.

Hortet, P., and H. Seegers. 1998b. Loss in milk yield and related composition changes resulting from clinical mastitis in dairy cows. Prev. Vet. Med. 37:1-20. http://dx.doi.org/10.1016/S01675877(98)00104-4.

Huijps, K., S. De Vliegher, T. J. G. M. Lam, and H. Hogeveen. 2009. Cost estimation of heifer mastitis in early lactation by stochastic modelling. Vet. Microbiol. 134:121-127. http://dx.doi. org/10.1016/j.vetmic.2008.09.018.

Huijps, K., H. Hogeveen, T. J. G. M. Lam, and A. G. J. M. Oude Lansink. 2010. Costs and efficacy of management measures to improve udder health on Dutch dairy farms. J. Dairy Sci. 93:115-124. http://dx.doi.org/10.3168/jds.2009-2412.

Huijps, K., T. J. G. M. Lam, and H. Hogeveen. 2008. Costs of mastitis: facts and perception. J. Dairy Res. 75:113-120. http://dx.doi. org/10.1017/S0022029907002932.

Hultgren, J., and C. Bergsten. 2001. Effects of a rubber-slatted flooring system on cleanliness and foot health in tied dairy cows. Prev. Vet. Med. 52:75-89. http://dx.doi.org/10.1016/S0167-5877(01)00237-9.

LEI. 2015. BINternet melkveehouderij (financial and agricultural dataset of the Dutch dairy sector). Accessed Apr. 10, 2016. http:// www.agrimatie.nl/SectorDashboard.aspx?subpubID $=2232 \&$ sector $\mathrm{ID}=2245$.

McInerney, J. P., K. S. Howe, and J. A. Schepers. 1992. A framework for the economic analysis of disease in farm livestock. Prev. Vet. Med. 13:137-154. http://dx.doi.org/10.1016/0167-5877(92)90098$\mathrm{Z}$

Rook, A. J., J. France, and M. S. Dhanoa. 1993. On the mathematical description of lactation curves. J. Agric. Sci. 121:97-102. http:// dx.doi.org/10.1017/S002185960007684X.

Santman-Berends, I. M. G. A., R. G. M. Olde Riekerink, O. C. Sampimon, G. van Schaik, and T. J. G. M. Lam. 2012. Incidence of subclinical mastitis in Dutch dairy heifers in the first 100 days in lactation and associated risk factors. J. Dairy Sci. 95:2476-2484. http://dx.doi.org/10.3168/jds.2011-4766.

Seabrook, M. F., and J. M. Wilkinson. 2000. Stockpersons' attitudes to the husbandry of dairy cows. Vet. Rec. 147:157-160. http:// dx.doi.org/10.1136/vr.147.6.157.

Seegers, H., C. Fourichon, and F. Beaudeau. 2003. Production effects related to mastitis and mastitis economics in dairy cattle herds. Vet. Res. 34:475-491. http://dx.doi.org/10.1051/vetres:2003027.

Sørensen, L. P., T. Mark, M. K. Sørensen, and S. Østergaard. 2010. Economic values and expected effect of selection index for pathogen-specific mastitis under Danish conditions. J. Dairy Sci. 93:358-369. http://dx.doi.org/10.3168/jds.2009-2506.

van den Borne, B. H. P., G. van Schaik, T. J. G. M. Lam, and M. Nielen. 2010. Variation in herd level mastitis indicators between primiand multiparae in Dutch dairy herds. Prev. Vet. Med. 96:49-55. http://dx.doi.org/10.1016/j.prevetmed.2010.05.010.

Vermeij, I. 2014. Kwantitatieve Informatie Veehouderij 2013-2014 (Quantitative Information Livestock Farming 2013-2014). Livestock Research, Wageningen UR, the Netherlands.

Wilson, D. J., R. N. Gonzalez, K. L. Case, L. L. Garrison, and Y. T. Gröhn. 1999. Comparison of seven antibiotic treatments with no treatment for bacteriological efficacy against bovine mastitis pathogens. J. Dairy Sci. 82:1664-1670. http://dx.doi.org/10.3168/ jds.S0022-0302(99)75395-6.

Wood, P. D. P. 1967. Algebraic model of the lactation curve in cattle. Nature 216:164-165.

Yalcin, C., A. W. Stott, D. N. Logue, and J. Gunn. 1999. The economic impact of mastitis-control procedures used in Scottish dairy herds with high bulk-tank somatic-cell counts. Prev. Vet. Med. 41:135-149. http://dx.doi.org/10.1016/S0167-5877(99)00052-5. 